\title{
27 \\ Re-purposing Paradise: Tourism, Image and Affect
}

\author{
Kalissa Alexeyeff
}

The words 'Pacific', 'island', and 'paradise' are synonymous with each other in the western imaginary. It is an association that has a long trajectory originating in sixteenth-century Spanish expeditions and culminating in the travels of eighteenth- and nineteenth-century explorers, evangelists, traders and settlers. Collectively, these European 'tours' generated - through their images, texts, and collections - what might be termed the first 'paradise tourism' in the region. Occurring relatively late on the colonial stage, these incursions reinforced the "utopian significance of the Pacific islands as the last "unspoiled" locations on the earth'. ${ }^{1}$ It is a significance that has been retraced and retracked in the (post)colonial period through literature, popular film and music, media and particularly, through the material culture of mass-tourism.

As a persistent and ubiquitous trope 'Pacific paradise' fuels fantasies of abundance and bounty. Images of crystal clear lagoons, iridescent sand and gently swaying palm trees that shade beckoning young women have been critiqued by academics for their racist and sexist

1 Sharae Decard, 2010, Paradise Discourse, Imperialism and Globalization: Exploiting Eden, New York and London: Routledge, p. 12. 
underpinnings. ${ }^{2}$ Artists have thoroughly deconstructed stereotypical images of paradise for example, through reimagining the 'dusky maiden' in the works of Rosanna Raymond, Yuki Kihara and Sue Pearson. ${ }^{3}$ Here I build on the insights developed in this body of work as well as exploring another highly potent, and somewhat curious, aspect of the 'Pacific paradise' trope. In this paper, I explore how images and imaginaries of 'Pacific paradise', especially via the material culture of tourism, are adopted by locals across a transnational Pacific community, to articulate heartfelt emotions about their homeland, their families and personal aspirations. In doing so, they bundle together political, economic and affective economies and make 'paradise' a key register of what has usefully been called 'felt modernity'. ${ }^{4}$

What emerges is a wide and often ambivalent range of local engagement with 'Pacific paradise' that amounts to more than outright rejection of this trope (although there are certainly contexts in which this refusal occurs). Some of the examples I present both deconstruct and adopt 'paradise' ironically, as many scholars and artists have done previously. But they engage less in a process of escaping or subverting than speaking through this trope. In these instances, generic images of paradise are re-purposed to express personal and community attachments and desires. I choose the word 're-purpose' carefully in order to emphasise the ambivalence attached to this trope. ${ }^{5}$ In the examples below, 'Pacific paradise' is not simply taken up and given new meaning as terms such as 'appropriation' and 're-appropriation'

2 Patty O'Brien, 2006, The Pacific Muse: Exotic Femininity and the Colonial Pacific, Seattle: University of Washington Press; Jane C. Desmond, 1999, Staging Tourism: Bodies on Display from Waikiki to Sea World, Chicago: University of Chicago Press; Margaret Jolly, 1997, 'From Point Venus to Bali Ha'i: Eroticism and exoticism in representations of the Pacific', in Sites of Desire, Economies of Pleasure: Sexualities in Asia and the Pacific, ed.Lorraine Manderson and Margaret Jolly, pp. 99-122, Chicago: University of Chicago Press; Teresia Teaiwa, 1994, 'Bikinis and other S/pacific N/oceans', The Contemporary Pacific 6(1): 87-109; Haunani-Kay Trask, 1993, '“Lovely hula hands": Corporate tourism and the prostitution of Hawaiian culture', in From a Native Daughter: Colonialism and Sovereignty in Hawai'i, pp. 179-97, Maine: Common Courage Press.

3 See Marata A. Tamaira, 2010, 'From full dusk to full tusk: Reimagining the "dusky maiden" through the visual arts', The Contemporary Pacific 22(1): 1-35; and also Yuki Kihara, 2013, Undressing the Pacific, Dunedin: Hocken Collection, University of Otago; Selina Tusitala Marsh, 'Hawai'i: Prelude to a Journey', this volume; Courtney Sina Meredith, 'Ibu \& Tufuga' and 'Great Works', this volume.

4 Koichi Iwabuchi (ed.), 2004, Feeling Asian Modernities: Transnational Consumption of Japanese TV Drama, Hong Kong: University of Hong Kong Press.

5 I have John Taylor to thank for suggesting the term after reading an early version of this paper. 
tend to suggest, but rather 'paradise' retains the traces of gendered and raced (post)colonial histories as well as marks of the political economy in the global present.

\section{Paradise as commodity fetishism}

'As a destination for the tourist, the Pacific is a creation of capitalism', Michael Hall incisively remarks in an early discussion of myths of the Pacific as untouched paradise. ${ }^{6}$ Tropes of virginal yet bountiful landscapes create an imperial politics of place' ${ }^{7}$ that are intertwined with the global political economy and, most significantly, serve to mask histories of exploitation of land and people. ${ }^{8}$ Teresia Teaiwa's work on Bikini Atoll is still the most striking example of this masking process. In this piece, she outlines how the 'bikini' bathing suit named after the atoll was created from myths of the island paradise as a pacific and feminised space. ${ }^{9}$ Crucially, this 'bikini' served to strategically conceal the nuclear testing that occurred on Bikini Atoll, rendering the history of colonialism and ecological racism invisible to a western audience.

Beyond the Pacific, the paradise trope has similarly functioned to both mark and mask colonial and capitalist enterprise. The original theological meaning of 'paradise' underwent both religious and secular transformations and gained increased traction in response to fifteenthcentury European colonial expansion, serving to both produce and veil the material exploitation of newly acquired colonies in the Americas. ${ }^{10}$ Paradise, Sharae Decard's argues in Paradise Discourse, Imperialism and Globalization: Exploiting Eden:

\footnotetext{
6 C. Michael Hall, 1998, 'Making the Pacific: Globalisation, modernity and myth', in Destinations: Cultural Landscapes of Tourism, ed. Greg Ringer, pp. 140-53, London and New York: Routledge, p. 141.

7 John Connell, 2003, 'Island dreaming: The contemplation of Polynesian paradise', Journal of Historical Geography 29(4): 554-81, p. 555.

8 Miriam Kahn, 2011, Tahiti Beyond the Postcard: Power, Place, and Everyday Life, Seattle: University of Washington Press.

9 Teaiwa, 'Bikinis and other S/pacific N/oceans'.

10 See Decard, Paradise Discourse, Imperialism and Globalization.
} 
is a value-laden discourse related to profit, labour, and exploitation of resources both human and environmental whose very appearance or irrelevance or 'death by ubiquity' shields the process it perniciously conceals. Paradise is inextricably linked to the long modernity of the capitalist world-system. ${ }^{11}$

Here the trope of paradise operates as a form of commodity fetishism that both emerges from, and mystifies, the material conditions to which it is attached. As the early colonial fantasy of paradise as labourfree profit and accumulation of wealth was enabled by forced labour and land alienation, so too in the twenty-first century we witness the economic transition from slavery and indenture to tourism and a refiguration of tropes of paradise. Paradise as bounty and abundance works to obscure exploitative relations of the present day as tourism resorts displace local homes, and fresh towels, flowers and fruit appear in hotel rooms as if by magic. ${ }^{12}$ Contemporary images of paradise are no longer sites ripe for extraction of material goods (gold, sugar, cotton) but are now 'sights'. That is, commodified spectacles of luxury and leisure. $^{13}$

The ways in which paradise discourse enables, legitimises and obscures relations of global capitalism informs the following analysis of Cook Islands tourism imagery. I extend this analysis to explore the role of 'paradise' in local rather than western imaginaries. While much has been said about the instrumental potency of 'paradise' for 'the West', it is often implicitly assumed that local engagement amounts to simple rejection or dismissal of the notion of 'paradise'. Especially in tourism scholarship, 'Pacific paradise' is portrayed principally as myth drummed up by the tourist industry. This assumption is implicit in analyses that aim to look 'beyond the postcard' or 'behind the smile', and is also more broadly evident in ideas of 'staged authenticity' and the commodification of experience that continue to dominate tourism

11 Ibid., p. 2.

12 'Paradise discourse' operates through oppositional imagery of Eden and apocalypse (ibid., p. 3). This is a point clearly demonstrated in Teaiwa's work and it is a distinction that is potentially useful for thinking through the classificatory divides between Melanesia and Polynesia, as well as ideas about 'failed states' and environmental disasters such as hurricanes and global warming as they are inflected in the Pacific. See Teaiwa, 'Bikinis and other S/pacific N/oceans'.

13 Decard, Paradise Discourse, Imperialism and Globalization, p. 16. 
studies. ${ }^{14}$ In contrast to this line of argument, the examples below demonstrate that 'paradise' operates as an affective geography for local expression of what is valued, including ideas of personal success and failure and, significantly, ways of imagining and managing the contradictions of modern life. These contradictions coalesce on the experiences of the global tourist industry as well as those of migration and transnationalism produced by global capital.

\section{Touring paradise}

In the Cook Islands, as throughout much of the Pacific, tourism is the primary industry accounting for at least 70 per cent of the nations' Gross Domestic Product (GDP). The Cook Islands is a group of 15 islands in central Polynesia with a resident population of approximately $18,000 .{ }^{15}$ Rarotonga, the main island of the group and destination of most tourists, has dramatic volcanic peaks, a large lagoon and lush tropical vegetation (as well as large-scale hotels and requisite services). Approximately 90,000 tourists visit every year and, on Rarotonga, they make up one fifth of the population at any given time.${ }^{16}$ Tourism and tourists are thus highly visible all over the island, and the industry plays a major role in employment. At least one person from every family works in the tourism industry in some capacity or another. Tourism also plays a major role in the presentation of self on a daily basis. Tourists outnumber locals on the bus, at retail outlets and especially on the beach. The tourist gaze is also to be negotiated. Cook Islanders complain about how tourists stare at locals whilst engaging in mundane activities such as shopping at the supermarket. It is as if 'they expect us to live in grass huts', one Cook Islander friend explained with exasperation, 'they think we should be living in the Stone Age'. ${ }^{17}$

14 Dean MacCannell, 1976, The Tourist: A New Theory of the Leisure Class, New York: Schocken Books; see also Erik Cohen's critique, 1998, 'Authenticity and commoditization in tourism', Annals of Tourism Research 15: 371-86; and Edward M. Bruner, 2005, Culture on Tour: Ethnographies of Travel, Chicago: University of Chicago Press.

15 Cook Islands Statistics Office, Ministry of Finance and Economic Management, 2010, Rarotonga: Cook Islands.

16 Ibid.

17 Conversation with 'Odile', 8 May 2011. Pseudonyms are adopted throughout this chapter and all potentially identifying material (images, locations and people) have been de-identified. 
Tourism is the main destination for development aid and assistance to the Cook Islands and it provides jobs in service, agriculture, construction and further, informal sectors such as craft and cultural production including dance and music. As well as these direct material impacts and conditions, tourism ensures regular international air-flights and somewhat less regular national transport between the smaller islands of the group. 'Island life' continues in a large part because of the income tourism generates and the infrastructure it provides. For example, it is not uncommon to see tourist buses, boats and venues being utilised for local events and activities such as weddings, school excursions, or even a trip to the taro plantation. Furthermore, cultural performances are said to take place far more often than they used to in pre-tourism days, and thus the industry is both seen as an opportunity to maintain cultural traditions, providing money and a reason to dance, sing, drum and carve. But tourism is also considered to represent the vanguard of western influences that are viewed as eroding traditional local forms. These contradictory and concurrently held views about the positive and negative dimensions of tourism reflect deep ambivalence about the tourism industry evidenced in debates about 'culture for sale', land alienation and, increasingly, environmental pollution. The often employed phrases 'prostitution' and 'bastardisation' point to the ambivalence felt towards tourism and tourists, and to the global processes of commodification and perceived loss of cultural ownership. ${ }^{18}$

As in many tropical islands, the 'paradise' trope is a central signifier of the Cook Islands tourist industry; 'Welcome to Paradise' or 'Kia Orana from Paradise' are stock phrases repeated at tourist shows, lagoon cruises, on postcards and on t-shirts. In this scenario, where tourism is ubiquitous and saturates everyday life on the Cook Islands, the trope functions intertextually as it is adopted by many Cook Islanders to summarise their world view and perception of their geographical surrounds. Cook Islanders often wax lyrical about their home as 'paradise'. A woman I lived with on Rarotonga in the late 1990s would often greet her neighbour: 'Ah, another beautiful day in paradise!' The phrase expressed both a genuine utterance that spoke

18 Kalissa Alexeyeff, 2008, 'Are you being served? Sex, humour and globalisation in the Cook Islands', Anthropological Forum 18(3): 287-93. 
to the warmth, light and smell of the day at hand as well as a partly ironic sentiment in its self-conscious mimicry of tourism advertising campaigns.

'Paradise' now also features prominently in status updates on Facebook as the medium that is hugely popular with transnational communities in the Cook Islands as elsewhere. The following post tellingly includes the phrase in English preceded by an update in Cook Islands Māori, reassuring friends that they have not been forgotten and that everything is well on the island. Indeed, the island is so abundant that the person has been too busy picking up all the rubbish (a phrase used to refer to overgrown grass and fallen leaves, palm fronds and nuts) to find time to go online:

Tangi Ke e te au taeake ... Kare kotou i ngaropoina iaku ... Kua tae meitaki ua mai ki te enua nei. E ngao angaanga, kua roa rava te aere anga kua roaroa te tita. Ka pukapuka akaou tatou a teia nga ra. Beautiful Day here in Paradise!

This lush 'paradise' references both the natural environment and, in other contexts, the people who live there, especially local women. Islanders are proud of their beautiful young women; national and regional beauty pageants are hugely popular amongst locals and winners retain their fame and celebrity throughout their lives. While these beautiful young women featured in tourism advertising during the 1990s, advertising campaigns during the 2000s attempted a shift from these stock images of feminised paradise filled with 'dusky maidens' towards more 'realistic' experiential images based around the slogan 'Cook Islands, Live Differently'. In an interview I conducted with the Tourism Cook Islands' marketing director who oversaw the new campaign, she described how this proved disconcerting for local audiences. Locals, she said, were 'appalled' by the campaign featuring exuberant larger women. They asked her, 'Why are you putting fat mamas in the picture? We have such beautiful girls. What [a] shame!'19

19 Interview with Glenda Tuaine, 4 July 2008. Colleen Ballerino Cohen has dubbed sentiments such as these as 'marketing paradise, making nation' a process by which 'island nations market feminised paradise landscapes to western tourists while encouraging their own citizens to identify with these as patriotic expressions'. Cohen, 'Marketing paradise, making nation', Annals of Tourism Research 22 (2): 404-21, cited in Decard, Paradise Discourse, Imperialism and Globalization, p. 21. 


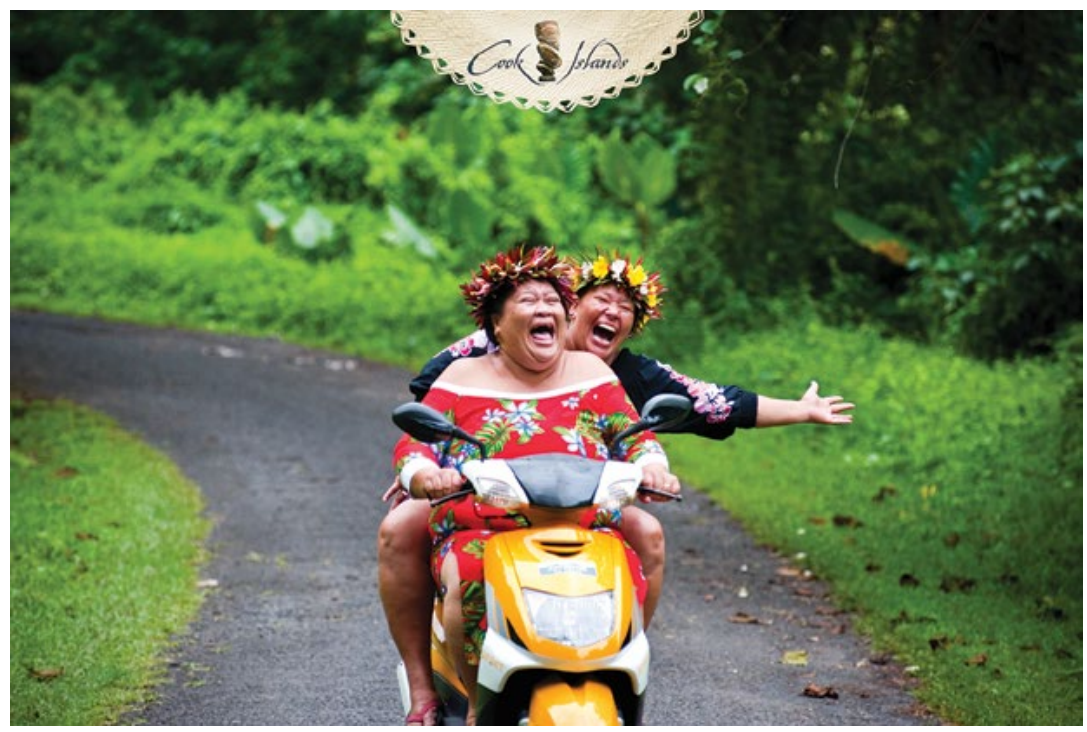

Figure 124. Tourism Cook Islands image of laughing mamas, 2015.

Source. Photo courtesy of Cook Islands Tourism Corporation.

The 'paradise' trope assumes a particular poignancy for Cook Islanders who have moved abroad. As a former New Zealand colony, the Cook Islands has an 'associated state' relationship, which means among other things that Cook Islanders travel on New Zealand passports and have automatic citizenship rights. Opportunity, in the form of higher wages, education and social welfare 'pull' Cook Islanders abroad, and now the vast majority of Cook Islanders live abroad, an estimated 60,000 in New Zealand and 15,000 in Australia (compared to 18,000 in the nation-state). Tourism and migration are intertwined in the Cook Islands' postcolonial history. Since the international airport opened on Rarotonga in 1974, tourism was earmarked as a key national growth area and concurrently locals began to migrate in unprecedented numbers to New Zealand. The majority of migrants settle permanently abroad but participate in transnational networks that encompass family who reside at home and those living in other countries. The images associated with Cook Islands tourism advertising provide a backdrop for those who have migrated to imagine their return home and to narrativise their experience of migration. 


\section{Picturing paradise}

As I visited various Cook Islanders in New Zealand one winter, I was struck that the images used to decorate the walls were the tourist posters and postcards of the Cook Islands as well as more generic prints depicting palms leaning into the lagoon at sunset. By contrast, these interiors were inhabited by people dressed in layers of warm clothing to combat the cold weather. This cold was exacerbated by the lack of insulation and limited heating. These images of paradise where not ironic appropriations of tourism advertising it seemed, but rather they appeared to starkly represent how the migrant dream of self-advancement and wealth was as illusory as the goal of returning to make paradise home.

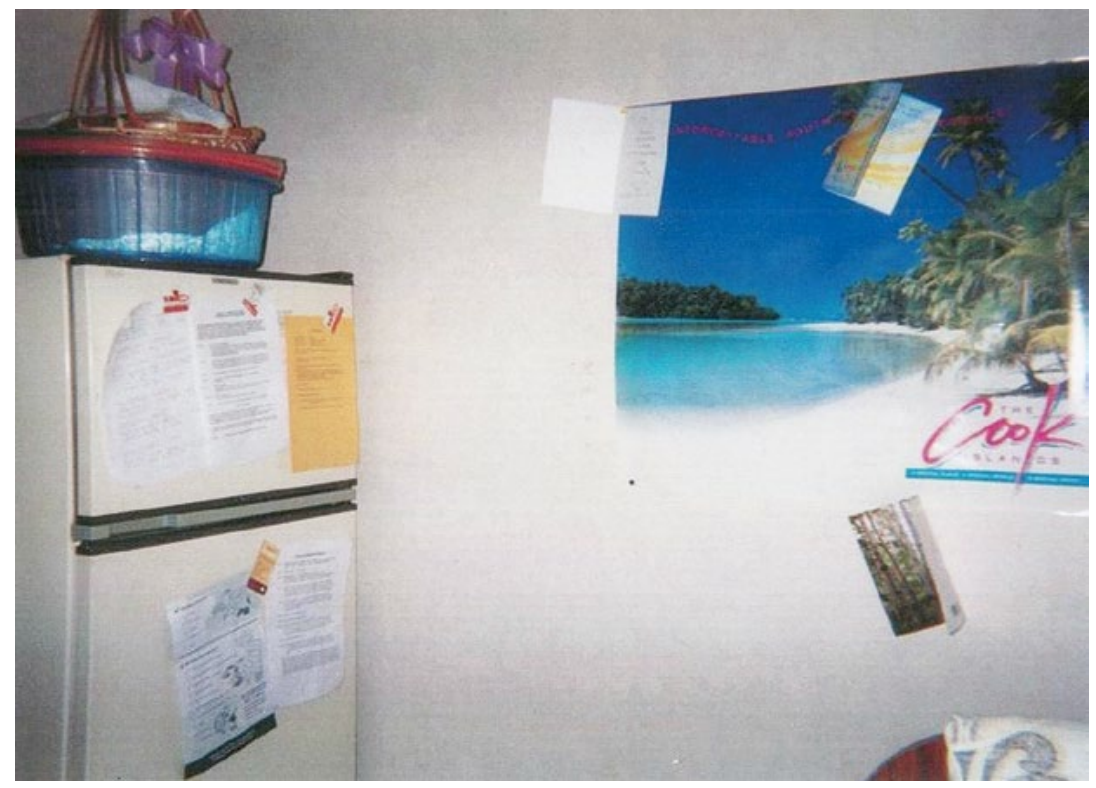

Figure 125. A kitchen with paradise poster.

Source. Photographed by Kalissa Alexeyeff, Otara, Auckland, 12 August 2000.

One house in which I frequently stayed in South Auckland was a particularly arresting example of this decorative style of re-purposing 'Pacific paradise'. The small house was rented by a woman, who lived there with her 80-year-old father who was visiting from the islands for medical treatment, and two of her teenage children. The elderly father first migrated to New Zealand to work in the timber industry. He came 
along with many Pacific Islander men, to fill labour shortages during the post-World War II period. He had returned to his home island after five years work and had only recently arrived back in New Zealand because of his ailing health and access to free and comprehensive health care. This move was to become permanent despite his wish to eventually die at home. Like all of his eight children, the woman who rented the house had grown up in the Cook Islands but she had moved to New Zealand in her early 20s (and now, all but one sibling lives abroad). She married, had children and worked on an assembly line at an electronics factory. After this industry suffered a decline in the late 1990s, she found work as a car park attendant. Although she returned annually to her home island for Christmas festivities and family reunions and expressed a deep sadness on these occasions that she didn't reside there, she felt she was 'too used to New Zealand' and besides, her three teenage children had been born and raised in Auckland had no desire to return 'home'. These children accompanied family members on trips to the Cook Islands sitting in rapt attention listening to their parents reminiscing together about the olden days'. These children also maintained transnational relationships with cousins through Facebook, phone texts and travel. While their ancestral home featured significantly in their self-identifications, they also felt they would be incredibly bored if they had to live there. Alongside boredom they expressed a certain awkwardness in their habitus at 'home'. One professed to me that they felt like a 'tourist' when they went on these trips home, 'because I take photos and have more money and better clothes than my cousins. But also because I want to go to the beach and I can't husk a coconut properly. My aunty called me a tourist once, she was laughing at me, and I felt pretty shamed. ${ }^{20}$

These conflicting attitudes to 'home' should not suggest that New Zealand, and Auckland in particular, is divorced from 'Island life'. Two-thirds of all Pacific people residing in New Zealand (7.4 per cent of the population, 295,941 people identified with one or more Pacific ethnic group), ${ }^{21}$ live in South and West Auckland. Retail outlets and markets in these areas provide local produce, garments,

20 Personal communication, 'Tangi', 30 March 2012.

21 Statistics New Zealand, 2014, 2013 Census Quick Stats about Culture and Identity. 
music and wealth such as fine mats in abundance. Samoan, Tongan and Cook Islander churches and community halls figure prominently on the main roads, and performing arts, sports competitions and other community festivals are dotted throughout the year. These activities and objects attest to the 'super-vibrancy' of Pacific Islander cultural production and consumption abroad. ${ }^{22}$ Back home and outside of tourism contexts, these practices continue in largely attenuated forms or for 'export' to family who lived abroad.

A proliferation of local cultural forms does little however to ameliorate longing for homeland at the level of lived experience and in familial narratives across generations. One might suggest that this cultural production, consumption and the sentiments they engender feeds this yearning. For example, the large taro industry that operates from the Pacific Islands to New Zealand supplies nostalgic demands, but also people invariably comment that taro doesn't 'taste the same as it does at home'. Songs written by string band groups that proliferate in the diaspora (and are hugely popular with 'home' audiences as well), similarly voice sentiments of loss and yearning for a home often signified as a paradisial landscape.

Island paradise as trope of home as well as that which is displaced was evident in my friend's house in South Auckland. Shell 'ei (necklaces) hung in long curtains from each doorway, softly chinking as one passed through them. In the main rooms of the house, woven hats and fans and plastic flowers adorned the architraves, and posters of the 'paradise' produced by Tourism Cook Islands decorated the walls. These touristic images were framed with shell necklaces, invitations to Cook Islander events such as weddings and community fundraisers, and photographs of family members at these events.

22 Cathy A. Small, 2011 [1997], Voyages: From Tongan Villages to American Suburbs, Ithaca and London: Cornell University Press, p. 151. 


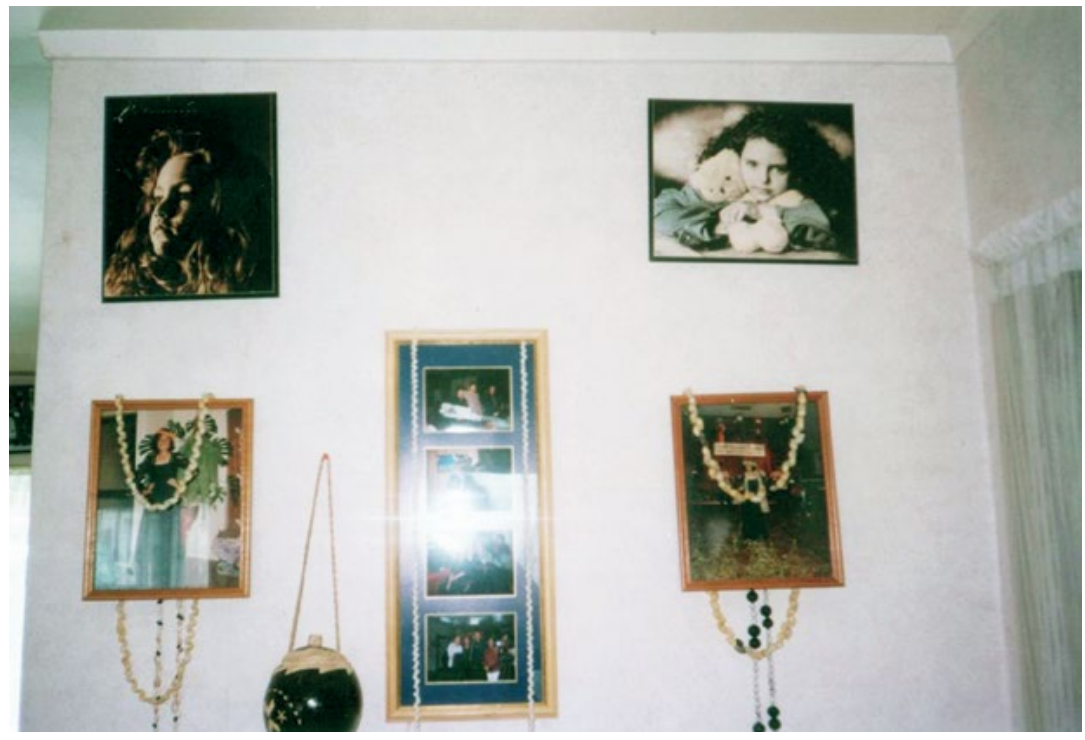

Figure 126. Living room wall, South Auckland.

Source. Photographed by Kalissa Alexeyeff, Otara, Auckland, 12 August 2000.

Embedding global mass-produced and generic images in local histories via personal photographs, significant objects and text is a phenomenon observed by Christopher Pinney and others, ${ }^{23}$ who view these practices as acts that link material objects to practices of memorialisation and projection. ${ }^{24}$ As a visual tableau, these images and objets d'art act as repositories of both memory and aspiration; visually communicating collective and personal history and future identifications and trajectories.

Similarly at the South Auckland house, the images and artefacts display collective and personal histories by channelling the affective force of the 'paradise' trope. 'Paradise' in this tableau represents natural beauty and the smiling warmth of its people. It communicates genuine love for homeland and pride in cultural heritage. Framing and layering images of 'paradise' with photographs of people and gifted objects also visually gestures to a form of sociality in which family, community, and culturally styled generosity are central values.

23 Christopher Pinney, 1997, Camera Indica: The Social Life of Indian Photographs, London: Reaktion Books.

24 Daniel Miller, 2008, 'Migration, material culture and tragedy: Four moments in Caribbean migration', Mobilities 3(3): 397-413. 


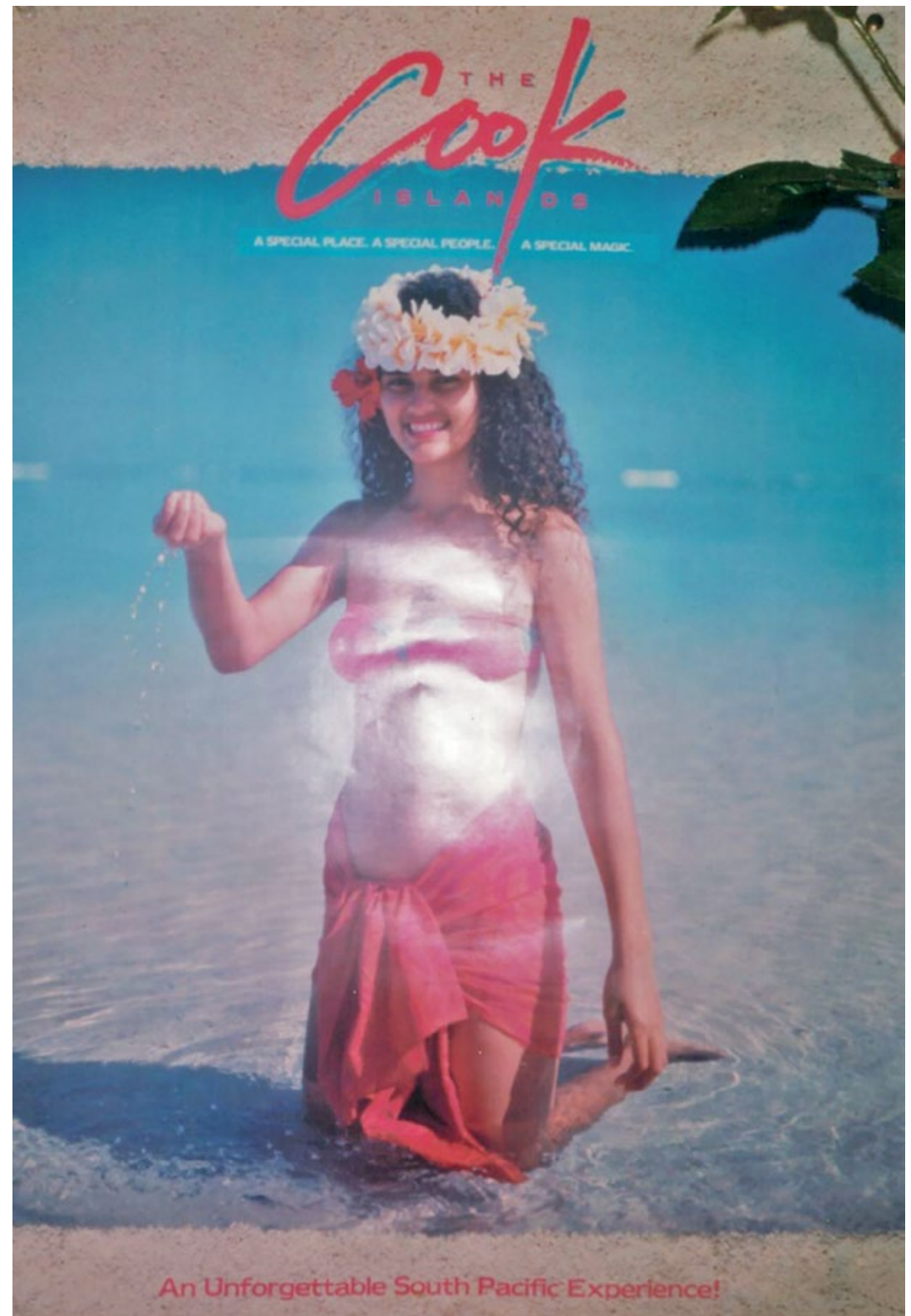

Figure 127. 'Endless summer': A Cook Islands Tourism poster on a kichen wall.

Source. Photographed by Kalissa Alexeyeff, Otara, Auckland, 12 August 2000. 
Paradise is, however, an elusive destination. Paradise is always elsewhere; registering nostalgia for a place that has once been, as well as, and crucially, encapsulating future anticipatory longing. ${ }^{25}$ For many Cook Islanders, including the inhabitants of this particular South Auckland house, the dream of the future is narrated through the paradise trope as a yearning to earn enough money to return and build a home on their family land. For many this land, especially beachfront sections, is leased on 99-year contracts to local elites and to foreign interests to develop tourism enterprises. Back in New Zealand, individuals who migrated to 'better themselves' through education and higher paying jobs may find the high cost of living and debt often trap them at the lower end of New Zealand's socio-economic scale. 'Paradise' home is a place of both projected love and longing and a location that is always deferred, a site to which one returns only briefly for events such as Christmas celebrations and in one's dreams.

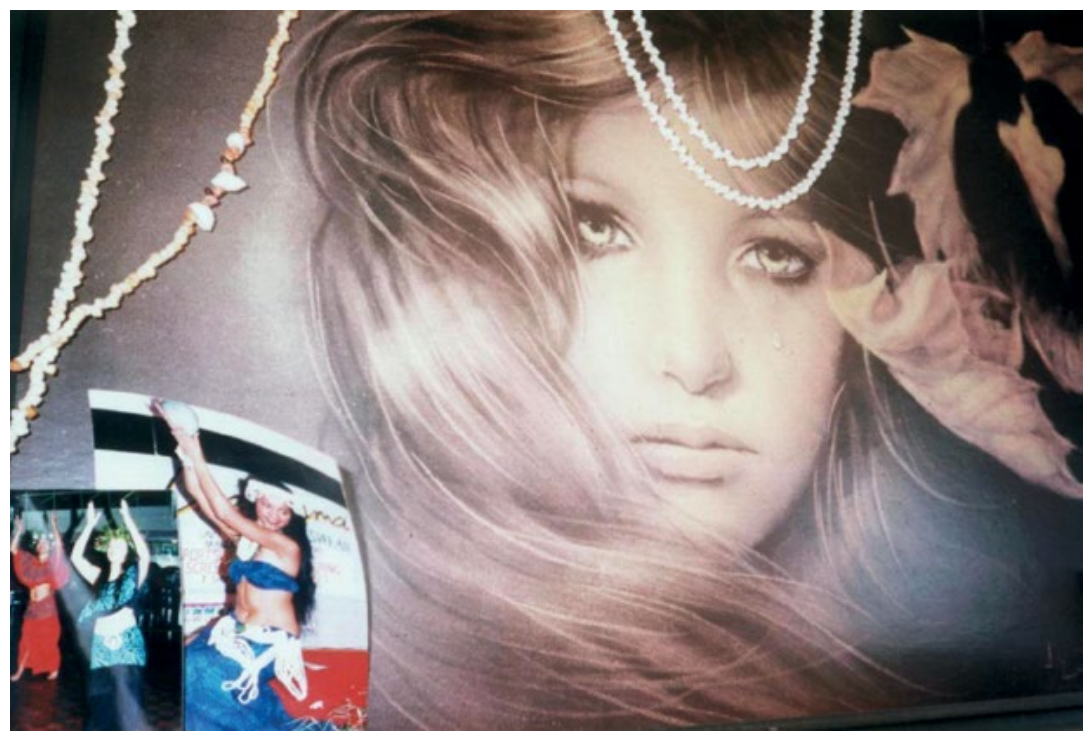

Figure 128. 'Autumnal crying woman' poster and family photos.

Source. Photographed by Kalissa Alexeyeff, Otara, Auckland, 12 August 2000.

In the South Auckland house, longing and nostalgia for a paradise deferred were visually represented through the placement of tourist images, souvenirs and family photographs alongside poster art of

25 Decard, Paradise Discourse, Imperialism and Globalization, p. 4. 
(white) women and young girls crying, the latter often embracing soft toys for comfort. These crying images made for an unusual juxtaposition with the far more upbeat images of 'paradise' expressed through tourist posters. It was a juxtaposition that visiting family would comment upon and tease the woman with comments such as, 'Are you trying to make us all sad?' The owner in turn, could not, or would not, fully articulate her interest in these pictures beyond saying she liked them, and that she liked that they were crying. She acknowledged they were a bit unusual compared to other Cook Islands interiors, although she stated that she did not find them sad but rather found these images aesthetically pleasing and somehow comforting. ${ }^{26}$

The woman's frequent reminiscing and also singing about her homeland, further articulated this juxtaposition. Her small backyard in the Auckland suburb was often cold and wet but nevertheless she coaxed cuttings of gardenia and rauti (Cordyline Terminalis) and even taro to grow. It is an image I cannot resist comparing to the expansive view of the sun-drenched lagoon that one could watch from her family house back home - a view that is in some ways a reflection of 'paradise' visual imagery, and one that is made more poignant by the fact that the 100-year-old family home from which I took the photo was destroyed by a cyclone in the mid-2000s.

26 'Crying art' is a popular genre of painting and mass-produced posters and prints. They most famous is The Crying Boy painting by Italian painter Bruno Amadio, also known as Bragolin, in the 1950s. In urban legend the image is thought to be cursed, bringing bad luck and fire to owners' homes. The Hollywood movie Big Eyes, directed by Tom Burton (2014), recounts another notorious story of artist Margaret Keane, who painted often teary-eyed girls, and whose work was passed off by her husband, Walter, as his own. 


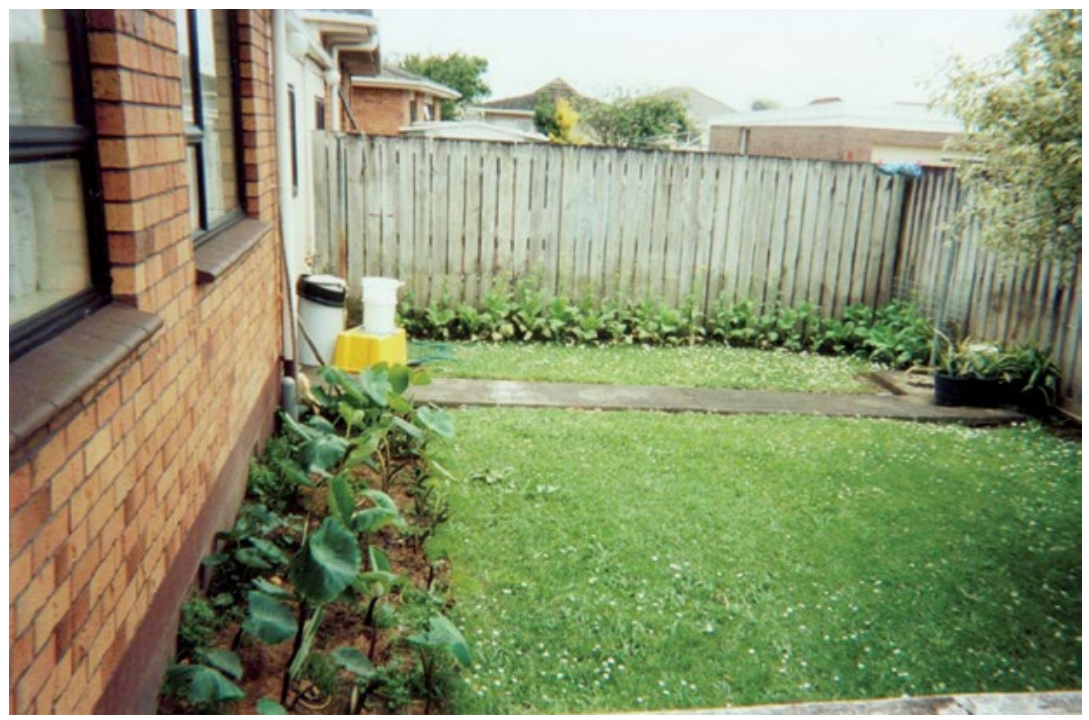

Figure 129. South Auckland backyard.

Source. Photographed by Kalissa Alexeyeff, Otara, Auckland, 12 August 2000.

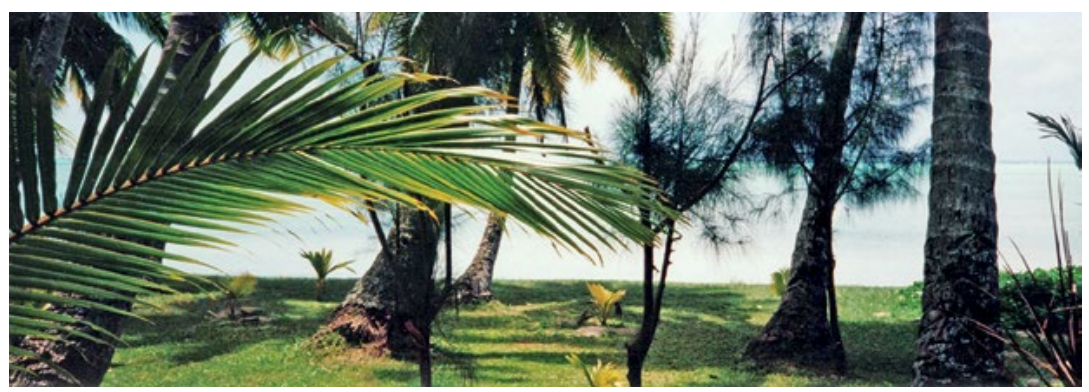

Figure 130. View from the family land looking out across the lagoon, Rarotonga.

Source. Photographed by Kalissa Alexeyeff, Rarotonga, Cook Islands, 2 January 1997.

\section{Re-purposing paradise}

Both the exterior and interior of the South Auckland house presented a vivid contrast between the 'endless summer' of 'paradise' and the cold, outer-suburban reality of many Cook Islands migrants in New Zealand. Daniel Miller similarly details 'the tragedy of migration' and the role of material cultural in evoking and enabling related 
sentiments. ${ }^{27}$ Particular houses of Caribbean migrants in London with whom he worked indexed key contradictions in migrant trajectories, including aspirations to improve one's lot in life, the 'myth of return home', success and failure, as well as broader historical and economic stratification that mark these personal narratives. Like some of Miller's more 'quirky' individuals and their interior decoration styles, the woman living in the South Auckland house was unusual in the care she took to decorate her interiors. While many Cook Islands migrants will casually stick family photos and memorabilia to walls of their rental house, more permanent ornamentation is usually minimal. Nevertheless, I feel confident suggesting (on the back of Miller's work) that the 'Pacific paradise' represented in tourist imagery of smiling, bikini-clad brown girls interspersed with pictures of crying white girls was not a haphazard arrangement nor simply an idiosyncratic decorative style. This arrangement drew upon the racialised and gendered dimensions of the paradise trope, re-purposing it to inflect her experience of migration, but nevertheless revealing and masking the contradictions in her life-history-her sense of self and place. For this woman, her house expressed her deeply held familial and cultural bonds, as well enacting a longing for that which was beyond her reach. Taking on board the idea that 'paradise discourse' has been repeatedly mobilised in the service of capitalist modes of production, exploitation of labour and capital accumulation, ${ }^{28}$ it is not an especially large leap to argue that the South Auckland house serves both to reveal, as well as revel in, the contradictions of a racialised capitalist modernitythe promises of great economic mobility, expanded horizons and freedom in contrast to the more truncated reality of structural poverty embedded in formations of racism that characterises settler colonial societies globally.

'Paradise' has a long historical trajectory in the Pacific as the emblem of Pacific tourism. It is a trope that is embedded in local everyday social life and lived experience. As such, tourism - and its material culture - is entwined with local economics, politics and sensibilities as much as it is a vehicle of global capitalism and other macro trends such as emigration and patterns of labour mobility and national economic development. In the little South Auckland house, as well as in the practices of Cook Islanders at home, 'paradise' serves as

27 Miller, 'Migration, material culture and tragedy'.

28 Decard, Paradise Discourse, Imperialism and Globalization, p. 21. 
a backdrop to register the contradictions of economic, social and affective modernities poignantly illustrating how 'paradise' is not simply an image for outsiders but also a story upon which locals may map a geography of longing concerning here and there, now and then, and into spaces of the future.

\section{References}

Alexeyeff, Kalissa. 2008. 'Are you being served? Sex, humour and globalisation in the Cook Islands.' Anthropological Forum 18(3): 287-93.

Big Eyes. 2014. Directed by Tom Burton.

Bruner, Edward M. 2005. Culture on Tour: Ethnographies of Travel. Chicago: University of Chicago Press.

Cohen, Erik. 1998. 'Authenticity and commoditization in tourism.' Annals of Tourism Research 15: 371-86.

Connell, John. 2003. 'Island dreaming: The contemplation of Polynesian paradise.' Journal of Historical Geography 29(4): 554-81.

Cook Islands Statistics Office, Ministry of Finance and Economic Management. 2010. Rarotonga: Cook Islands. Online: www.mfem. gov.ck/statistics (accessed 3 March 2016).

Decard, Sharae. 2010. Paradise Discourse, Imperialism and Globalization: Exploiting Eden. New York and London: Routledge.

Desmond, Jane C. 1999. Staging Tourism: Bodies on Display from Waikiki to Sea World. Chicago: University of Chicago Press.

Hall, C. Michael. 1998. 'Making the Pacific: Globalisation, modernity and myth.' In Destinations: Cultural Landscapes of Tourism, ed. Greg Ringer, pp. 140-53. London and New York: Routledge.

Iwabuchi, Koichi (ed.). 2004. Feeling Asian Modernities: Transnational Consumption of Japanese TV Drama. Hong Kong: University of Hong Kong Press. 
Jolly, Margaret. 1997. 'From Point Venus to Bali Ha'i: Eroticism and exoticism in representations of the Pacific.' In Sites of Desire, Economies of Pleasure: Sexualities in Asia and the Pacific, ed.Lorraine Manderson and Margaret Jolly, pp. 99-122. Chicago: University of Chicago Press.

Kahn, Miriam. 2011. Tahiti Beyond the Postcard: Power, Place, and Everyday Life. Seattle: University of Washington Press.

Kihara, Yuki. 2013. Undressing the Pacific. Dunedin: Hocken Collection, University of Otago. Online: shigeyukikihara.files.wordpress. com/2013/04/kihara-ecatalogue.pdf (accessed 3 March 2016).

MacCannell, Dean. 1976. The Tourist: A New Theory of the Leisure Class. New York: Schocken Books.

Miller, Daniel. 2008. 'Migration, material culture and tragedy: Four moments in Caribbean migration.' Mobilities 3(3): 397-413.

O'Brien, Patty. 2006. The Pacific Muse: Exotic Femininity and the Colonial Pacific. Seattle: University of Washington Press.

Pinney, Christopher. 1997. Camera Indica: The Social Life of Indian Photographs. London: Reaktion Books.

Small, Cathy A. 2011 [1997]. Voyages: From Tongan Villages to American Suburbs. Ithaca and London: Cornell University Press.

Statistics New Zealand, 2014. 2013 Census Quick Stats about Culture and Identity. Online: www.stats.govt.nz/Census/2013-census/ profile-and-summary-reports/quickstats-culture-identity/pacificpeoples.aspx (accessed 3 March 2016).

Tamaira, Marata A. 2010. 'From full dusk to full tusk: Reimagining the "dusky maiden" through the visual arts.' The Contemporary Pacific 22(1): $1-35$.

Teaiwa, Teresia. 1994. 'Bikinis and other S/pacific N/oceans.' The Contemporary Pacific 6(1): 87-109.

Trask, Haunani-Kay. 1993. "Lovely hula hands": Corporate tourism and the prostitution of Hawaiian culture.' In From a Native Daughter: Colonialism and Sovereignty in Hawai'i, pp. 179-97. Maine: Common Courage Press. 
This text is taken from Touring Pacific Cultures, edited by Kalissa Alexeyeff and John Taylor, published 2016 by ANU Press, The Australian National University, Canberra, Australia. 